\title{
Mucilaginibacter rigui sp. nov., isolated from wetland freshwater, and emended description of the genus Mucilaginibacter
}

\begin{abstract}
Correspondence
Chi Nam Seong

scnu@scnu.ac.kr
\end{abstract}

\author{
Keun Sik Baik, ${ }^{1}$ Seong Chan Park, ${ }^{1}$ Eun Mi Kim, ${ }^{1,2}$ Chae Hong Lim ${ }^{1}$ \\ and Chi Nam Seong ${ }^{1}$
${ }^{1}$ Department of Biology, College of Life Science and Natural Resources, Sunchon National University, Suncheon 540-742, Republic of Korea
${ }^{2}$ Department of Dental Hygiene, Gwangju Health College University, Gwangju, 506-701, Republic of Korea

\begin{abstract}
A non-motile, rod-shaped bacterium, designated strain $\mathrm{WPCB} 33^{\top}$, was isolated from freshwater collected from the Woopo wetland (Republic of Korea). Cells were Gram-reaction-negative, aerobic and catalase- and oxidase-positive. The major fatty acids were iso- $\mathrm{C}_{15 \text { :o }}$ and anteiso$\mathrm{C}_{15: 0}$. The strain contained MK-7 as the major isoprenoid quinone. The DNA G+C content was $47 \mathrm{~mol} \%$. A phylogenetic tree based on 16S rRNA gene sequences showed that strain WPCB $133^{\top}$ forms an independent lineage within the genus Mucilaginibacter. Strain WPCB133 ${ }^{\top}$ was distantly related to Mucilaginibacter kameinonensis $\mathrm{SCK}^{\top}$ (94.7\% sequence similarity), Mucilaginibacter paludis TPT56 ${ }^{\top}$ (94.5\%) and Mucilaginibacter gracilis TPT18 ${ }^{\top}$ (94.4\%). Phenotypic characteristics distinguished strain WPCB133 ${ }^{\top}$ from members of the genus Mucilaginibacter. On the basis of evidence presented in this study, strain WPCB $133^{\top}$ represents a novel species of the genus Mucilaginibacter, for which the name Mucilaginibacter rigui sp. nov. is proposed. The type strain is WPCB133 ${ }^{\top}\left(=\right.$ KCTC $12534^{\top}=$ NBRC $\left.101115^{\top}\right)$. An emended description of the genus Mucilaginibacter is also proposed.
\end{abstract}

Members of the phylum Bacteroidetes are widely distributed in aquatic and terrestrial habitats and have a key role in degrading various biopolymers (Floyd et al., 2005). The genus Mucilaginibacter, a member of the family Sphingobacteriaceae (Steyn et al., 1998; Pankratov et al., 2007), phylum Bacteroidetes, was proposed recently to group Gram-reaction-negative, non-spore-forming and non-motile rods producing large amounts of extracellular polymeric substances (Pankratov et al., 2007). Cells of some species undergo a cyclic shape change during culture development. At the time of writing, the genus comprises only three species, Mucilaginibacter paludis and Mucilaginibacter gracilis isolated from acidic peat (Pankratov et al., 2007) and Mucilaginibacter kameinonensis isolated from garden soil (Urai et al., 2008). In the course of our study on wetland microbial diversity, a rodshaped bacterial strain, designated WPCB133 ${ }^{\mathrm{T}}$, was isolated from a freshwater sample and subjected to a polyphasic taxonomic investigation.

The GenBank/EMBL/DDBJ accession number for the 16S rRNA gene sequence of strain WPCB $133^{\top}$ is EU747841.

Scanning and transmission electron micrographs of cells of strain WPCB $133^{\top}$ are available with the online version of this paper.
Strain WPCB $133^{\mathrm{T}}$ was isolated from a freshwater sample collected from the wetland of Woopo $\left(35^{\circ} 33^{\prime} \mathrm{N} 128^{\circ} 25^{\prime} \mathrm{E}\right)$, located in the Republic of Korea, using the standard dilution plating technique. Isolation was achieved using PYGV agar (Staley, 1968) at $25{ }^{\circ} \mathrm{C}$ for 7 days. The isolate was routinely cultured on $\mathrm{R} 2 \mathrm{~A}$ agar and preserved at $-80{ }^{\circ} \mathrm{C}$ as a suspension in distilled water containing $20 \%$ glycerol $(\mathrm{w} / \mathrm{v})$.

Preparation of bacterial DNA and PCR amplification and sequencing of the 16S rRNA gene were carried out as described by Chun \& Goodfellow, (1995). The resultant sequence of strain $\mathrm{WPCB} 133^{\mathrm{T}}$ (1426 nt) was aligned manually against sequences obtained from the GenBank database. Phylogenetic trees were inferred from the regions available for all sequences (positions 33-1380; Escherichia coli numbering system) using the neighbour-joining (Saitou \& Nei, 1987) and the Fitch-Margoliash (Fitch \& Margoliash, 1967) methods. Evolutionary distance matrices were generated according to Jukes \& Cantor (1969). The resultant neighbour-joining tree topology was evaluated by bootstrap analyses (Felsenstein, 1985) based on 1000 resamplings. Alignment and phylogenetic analyses were carried out using the jPHYDIT program (available at http://chunlab.snu.ac.kr/jphydit/) and PAUP 4.0 (Swofford, 1998), as described by Chun et al., (2000). 
Preliminary sequence comparison with 16S rRNA gene sequences held in GenBank indicated that the isolate was closely related to the genus Mucilaginibacter. The newly determined sequence was then aligned manually against representatives of the phylum Bacteroidetes. Strain WPCB $133^{\mathrm{T}}$ showed the highest $16 \mathrm{~S}$ rRNA gene sequence similarity to $M$. kameinonensis $\mathrm{SCK}^{\mathrm{T}}(94.7 \%$ sequence similarity), M. paludis $\mathrm{TPT}^{5} 6^{\mathrm{T}}(94.5 \%)$ and M. gracilis $\mathrm{TPT}_{18} 8^{\mathrm{T}}(94.4 \%)$. Sequence similarity with other members of the family Sphingobacteriaceae was $<92 \%$. The neighbour-joining tree (Fig. 1) showed that strain WPCB133 ${ }^{\mathrm{T}}$ formed a monophyletic clade with the members of the genus Mucilaginibacter with $100 \%$ bootstrap support. The topology of the Fitch-Margoliash tree was essentially the same (data not shown).

As 16S rRNA gene sequence similarities between strain WPCB $133^{\mathrm{T}}$ and described species of the genus Mucilaginibacter were below the level indicative of relatedness at the species level (97\%; Stackebrandt \& Goebel, 1994), no DNA-DNA hybridization test was needed to define a novel species.

Growth was tested on nutrient (NA, Difco), tryptic soy (TSA, Difco), plate count (PCA, Difco), MM1 (Pankratov et al., 2007) and R2A (Difco) agars. Cells of strain WPCB133 $3^{\mathrm{T}}$ grown on $\mathrm{R} 2 \mathrm{~A}$ agar at $25^{\circ} \mathrm{C}$ for 3 days were used for physiological and biochemical tests and results were recorded for 10 days unless otherwise indicated. Cell morphology was observed by phase-contrast (TMS-F, Nikon), scanning (S-4800, Hitachi) and transmission electron (CM-20, Philips) microscopy using cells grown for 2 days at $25{ }^{\circ} \mathrm{C}$ on R2A. Cell life cycle was examined using cultures grown both on MM1 agar and in MM1 broth for up to 2 weeks. Motility was examined by observing cells in wet mounts using phase-contrast microscopy (Axioskop 40, Zeiss). The $\mathrm{pH}$ range for growth was determined on R2A agar. Medium sterilized by autoclaving was adjusted to $\mathrm{pH} \mathrm{4-11} \mathrm{(using} \mathrm{increments}$ of $1 \mathrm{pH}$ unit) by addition of $\mathrm{HCl}$ or $\mathrm{NaOH}$. Growth temperature $\left(4,10,15,20,25,30,37,40\right.$ and $\left.42{ }^{\circ} \mathrm{C}\right)$ and
$\mathrm{NaCl}$ tolerance $[0,1,2,3,5$ and $10 \%(\mathrm{w} / \mathrm{v})]$ were tested on R2A agar. Anaerobic growth on R2A agar was tested using the AnaeroPack-Anaero (Mitsubishi Gas Chemical). Catalase and oxidase activities were determined using 3\% $(\mathrm{v} / \mathrm{v})$ hydrogen peroxide and Kovacs' reagent (Kovacs, 1956), respectively. Hydrolysis of cellulose (filter paper) and chitin was tested by overlaying the respective substrates on R2A. Hydrolysis of CM-cellulose was assessed on R2A agar supplemented with $0.5 \%$ (w/v) CM-cellulose (Sigma). Plates were flooded with $0.2 \%$ aqueous Congo red dye solution followed by removal of extra dye and flooding the plate with $1 \mathrm{M} \mathrm{NaCl}$ solution. A clear zone around bacterial growth indicated positive hydrolysis. For assessing hydrolysis of alginate $(0.5 \%$ sodium alginate, $\mathrm{w} / \mathrm{v})$, casein $(2 \%$ skim milk, w/v), chitin ( $1 \%$ colloidal chitin, w/v), pectin $(0.5 \%, \mathrm{w} / \mathrm{v})$, starch $(0.2 \%$ soluble starch, w/v $)$, Ltyrosine $(0.5 \%, \mathrm{w} / \mathrm{v})$, Tween $20(1 \%, \mathrm{v} / \mathrm{v})$, Tween $80(1 \%$, $\mathrm{v} / \mathrm{v})$ and xylan $(1 \%, w / v)$, R2A agar was supplemented with each substrate at concentrations recommended by Smibert \& Krieg (1994). The presence of flexirubin-type pigments was tested using the $\mathrm{KOH}$ test as described by Bernardet et al. (2002). Acid production from sugars was examined by using phenol red broth base (Difco) containing $0.5 \%$ of each sugar. Other physiological and biochemical tests were performed using API 20E, API 20NE and API 50CH kits (bioMérieux) and the GN2 MicroPlate (Biolog). Enzymic activities were tested using the API ZYM kit (bioMérieux) following the manufacturer's instructions. Antibiotic resistance of strain $\mathrm{WPCB} 133^{\mathrm{T}}$ and reference strains was determined by using the disc diffusion method with commercial antibiotic-impregnated discs (BBL Becton Dickinson). After 5 days of incubation at $25{ }^{\circ} \mathrm{C}$ on R2A, the results were interpreted according to the guidelines set forth by the CLSI (2003).

The detailed results of morphological, physiological and biochemical analyses are given in Table 1 and the species description. Table 1 shows the phenotypic characteristics that differentiate strain WPCB $133^{\mathrm{T}}$ from M. kameinonensis, M. paludis and M. gracilis.

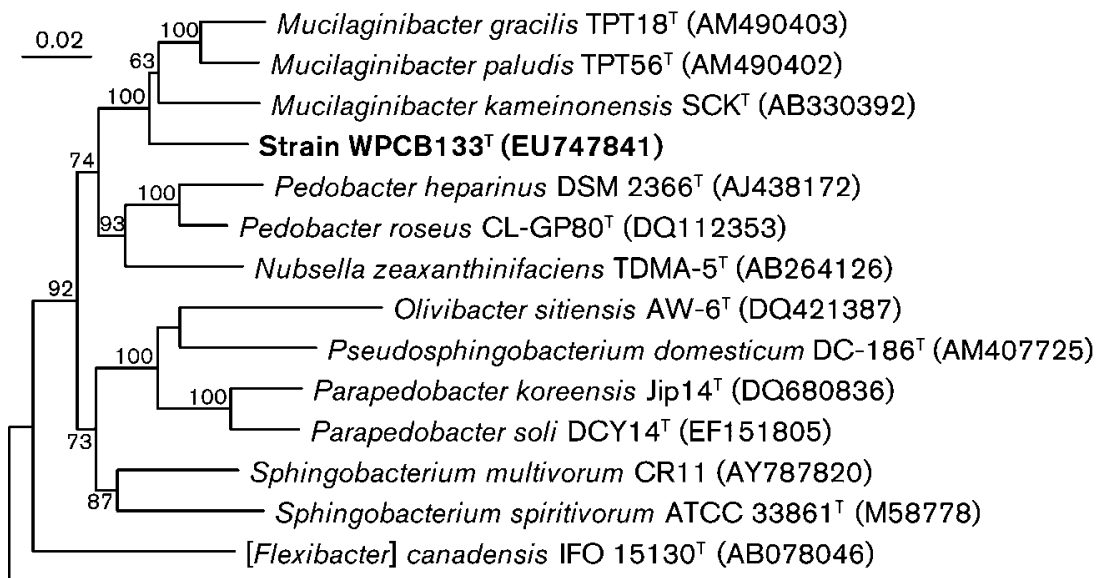

Hymenobacter rigui WPCB $131^{\top}$ (DQ089669)
Fig. 1. Neighbour-joining phylogenetic tree based on nearly complete 16S rRNA gene sequences showing relationships between strain $\mathrm{WPCB}_{133^{\top}}$, members of the genus Mucilaginibacter and representative members of the family Sphingobacteriaceae and of the phylum Bacteroidetes. Percentages at nodes are levels of bootstrap support ( $>50 \%$ ) based on neighbour-joining analyses of 1000 resampled datasets. The sequence of Hymenobacter rigui KCTC $12533^{\top}$ (DQ089669) was used as an outgroup. Bar, 0.02 nucleotide substitutions per position. 
Table 1. Phenotypic characteristics that differentiate strain WPCB133 ${ }^{\top}$ from other species of the genus Mucilaginibacter

Strains: 1, Mucilaginibacter rigui WPCB133 ${ }^{\mathrm{T}} ; 2$, M. paludis $\mathrm{TPT}^{5} 6^{\mathrm{T}} ; 3$, M. gracilis TPT18 ${ }^{\mathrm{T}}$ (data in columns $2-3$ from Pankratov et al., 2007); 4 , M. kameinonensis $\mathrm{SCK}^{\mathrm{T}}$ (Urai et al., 2008). +, Positive; -, negative; w, weakly positive; NA, data not available. All strains are positive for acid production from cellobiose, D-galactose, D-glucose, lactose, maltose, sucrose and trehalose and for catalase activity. All strains are negative for assimilation of citric acid and malic acid, Gram staining, motility and $\mathrm{H}_{2} \mathrm{~S}$ and indole production.

\begin{tabular}{|c|c|c|c|c|}
\hline Characteristic & 1 & 2 & 3 & 4 \\
\hline Cell arrangement & Pair, single & Single, pair, short chain & Single, pair, short chain & Irregular \\
\hline Cyclic cell shape change & - & + & + & NA \\
\hline \multicolumn{5}{|l|}{ Ranges for growth } \\
\hline Temperature $\left({ }^{\circ} \mathrm{C}\right)$ & $4-37$ & $2-33$ & $2-33$ & $5-30$ \\
\hline $\mathrm{pH}$ & $5-10$ & $4.2-8.2$ & $4.2-8.2$ & $4-9$ \\
\hline Flexirubin pigments & - & - & - & + \\
\hline Oxidase activity & + & + & + & - \\
\hline Hydrolysis of aesculin & + & - & - & + \\
\hline \multicolumn{5}{|l|}{ Acid production from: } \\
\hline Arabinose & - & - & + & + \\
\hline Arbutin & $\mathrm{w}$ & - & - & - \\
\hline D-Fructose & - & + & + & + \\
\hline Inulin & - & - & - & + \\
\hline D-Mannose & + & + & - & + \\
\hline Melezitose & - & - & - & + \\
\hline Melibiose & + & - & - & + \\
\hline Raffinose & - & - & + & + \\
\hline Salicin & $\mathrm{w}$ & - & + & + \\
\hline Trehalose & + & - & + & + \\
\hline D-Xylose & - & + & + & + \\
\hline \multicolumn{5}{|l|}{ Assimilation of: } \\
\hline$N$-Acetyl-D-glucosamine & + & + & - & $\mathrm{W}$ \\
\hline D-Galacturonic acid & - & + & - & - \\
\hline D-Gluconic acid & - & + & - & - \\
\hline D-Mannose & + & + & - & + \\
\hline Melibiose & + & - & - & + \\
\hline Raffinose & + & - & + & + \\
\hline myo-Inositol & - & + & - & - \\
\hline \multicolumn{5}{|l|}{ Susceptibility to:* } \\
\hline Chloramphenicol $(30 \mu \mathrm{g})$ & + & + & + & - \\
\hline Nalidixic acid $(30 \mu \mathrm{g})$ & + & + & + & - \\
\hline Erythromycin $(15 \mu \mathrm{g})$ & - & - & + & - \\
\hline DNA G $+C$ content $(\mathrm{mol} \%)$ & 47 & 46.1 & 42.4 & 43.7 \\
\hline Quinone(s) & MK-7 & MK-7, MK-6 & MK-7, MK-6 & MK-7 \\
\hline
\end{tabular}

${ }^{\star}$ Data from this study.

Cell biomass of strains WPCB $133^{\mathrm{T}}$ and M. kameinonensis $\mathrm{SCK}^{\mathrm{T}}$ for cellular fatty acid analysis was obtained from batch cultures grown in MM1 broth at $24{ }^{\circ} \mathrm{C}$ for 1 week. Analysis was performed by GLC according to the instructions of the Microbial Identification System (MIDI, 1999). Isoprenoid quinone analysis was performed by reversed phase TLC according to Collins (1985). The G $+\mathrm{C}$ content of the DNA was determined by using the thermal denaturation method of Marmur \& Doty (1962).

The cellular fatty acid profile of strain WPCB $133^{\mathrm{T}}$ is described in Table 2. Significant differences in the proportions of the predominant fatty acids (anteiso- $\mathrm{C}_{15: 0}$ and summed feature
3) were found between strain WPCB133 ${ }^{\mathrm{T}}$ and the type strains of related species. Quinone analysis revealed a spot that corresponded to menaquinone-7 (MK-7), but menaquinone6 (MK-6) was not detected. MK-7 predominates in all members of the family Sphingobacteriaceae, but some of them also contain minor amounts of MK-6 (Pankratov et al., 2007; Urai et al., 2008). The DNA G+C content of strain $\mathrm{WPCB}_{133^{\mathrm{T}}}$ was $47 \mathrm{~mol} \%$, a value slightly above the range reported for other species of the genus Mucilaginibacter (Pankratov et al., 2007; Urai et al., 2008).

A number of phenotypic characteristics clearly distinguished strain WPCB $133^{\mathrm{T}}$ from other species of the genus 
Table 2. Cellular fatty acid composition (\%) of strain WPCB133 ${ }^{\mathrm{T}}$ and the type strains of species of the genus Mucilaginibacter

Strains: 1, Mucilaginibacter rigui $\mathrm{WPCB}_{13}{ }^{\mathrm{T}} ; 2$, M. paludis $\mathrm{TPT}^{\mathrm{T}}{ }^{\mathrm{T}} ; 3$, M. gracilis TPT $18^{\mathrm{T}}$ (data in columns 2-3 from Pankratov et al., 2007). 4, M. kameinonensis SCK ${ }^{\mathrm{T}}$ (data in columns 1 and 4 from this study). -, Not detected; tr, trace amount $(<1 \%)$; ECL, equivalent chainlength. For fatty acid analysis, all strains studied were grown in MM1 broth at $24{ }^{\circ} \mathrm{C}$ for 1 week. Fatty acids amounting to $<1 \%$ of the total fatty acids in all strains are omitted.

\begin{tabular}{|c|c|c|c|c|}
\hline Fatty acid & 1 & 2 & 3 & 4 \\
\hline \multicolumn{5}{|l|}{ Straight-chain } \\
\hline $\mathrm{C}_{14: 0}$ & $\operatorname{tr}$ & $\operatorname{tr}$ & $\operatorname{tr}$ & 2.4 \\
\hline $\mathrm{C}_{15: 0}$ & - & 3.2 & 4.5 & 1.7 \\
\hline $\mathrm{C}_{16: 0}$ & $\operatorname{tr}$ & 3.1 & $\operatorname{tr}$ & 25.2 \\
\hline $\mathrm{C}_{17: 0}$ & - & $\operatorname{tr}$ & $\operatorname{tr}$ & 1.3 \\
\hline $\mathrm{C}_{18: 0}$ & - & $\operatorname{tr}$ & - & 19.5 \\
\hline \multicolumn{5}{|l|}{ Branched } \\
\hline iso- $\mathrm{C}_{13: 0}$ & $\operatorname{tr}$ & - & - & - \\
\hline iso- $\mathrm{C}_{14: 0}$ & 3.3 & - & - & - \\
\hline iso- $\mathrm{C}_{15: 0}$ & 34.1 & 15.7 & 32.2 & 10.0 \\
\hline iso- $\mathrm{C}_{15: 1} \mathrm{~F}$ & 1.9 & - & - & - \\
\hline iso- $\mathrm{C}_{16: 0}$ & 1.3 & 1.5 & $\operatorname{tr}$ & - \\
\hline iso- $\mathrm{C}_{17: 0}$ & 1.1 & $\operatorname{tr}$ & $\operatorname{tr}$ & - \\
\hline iso- $\mathrm{C}_{17: 1} \omega 9 c$ & 3.4 & $\operatorname{tr}$ & 2.7 & - \\
\hline anteiso- $\mathrm{C}_{15: 0}$ & 26.7 & 21.1 & 5.8 & - \\
\hline anteiso- $\mathrm{C}_{17: 0}$ & - & 4.5 & - & - \\
\hline \multicolumn{5}{|l|}{ Unsaturated } \\
\hline $\mathrm{C}_{14: 1} \omega 5 c$ & - & - & - & $\operatorname{tr}$ \\
\hline $\mathrm{C}_{15: 1} \omega 6 c$ & - & $\operatorname{tr}$ & 1.2 & - \\
\hline $\mathrm{C}_{16: 1} \omega 5 c$ & - & 5.8 & 2.6 & 1.3 \\
\hline $\mathrm{C}_{17: 1} \omega 8 c$ & - & $\operatorname{tr}$ & 1.5 & - \\
\hline $\mathrm{C}_{18: 1} \omega 5 c$ & 1.4 & - & - & - \\
\hline $\mathrm{C}_{18: 1} \omega 7 c$ & - & $\operatorname{tr}$ & - & 2.9 \\
\hline $\mathrm{C}_{18: 1} \omega 9 \mathrm{c}$ & - & $\operatorname{tr}$ & - & 2.5 \\
\hline \multicolumn{5}{|l|}{ Hydroxylated } \\
\hline $\mathrm{C}_{15: 0} 2-\mathrm{OH}$ & 2.1 & $\operatorname{tr}$ & $\operatorname{tr}$ & - \\
\hline $\mathrm{C}_{16: 0} 3-\mathrm{OH}$ & - & $\operatorname{tr}$ & $\operatorname{tr}$ & 2.3 \\
\hline $\mathrm{C}_{17: 0} 2-\mathrm{OH}$ & 1.1 & $\operatorname{tr}$ & $\operatorname{tr}$ & - \\
\hline iso- $\mathrm{C}_{15: 0} 3-\mathrm{OH}$ & 5.9 & 1.8 & 3.2 & - \\
\hline iso- $\mathrm{C}_{16: 0} 3-\mathrm{OH}$ & 2.6 & $\operatorname{tr}$ & $\operatorname{tr}$ & - \\
\hline iso- $\mathrm{C}_{17: 0} 3-\mathrm{OH}$ & 5.4 & 8.9 & 13.1 & 6.3 \\
\hline \multicolumn{5}{|l|}{ Unknown } \\
\hline ECL 14.263 & 2.2 & - & - & - \\
\hline \multicolumn{5}{|l|}{ Summed feature ${ }^{\star}$} \\
\hline 1 & 1.7 & - & - & - \\
\hline 3 & $\operatorname{tr}$ & 24.7 & 21.5 & 24.2 \\
\hline 4 & 1.7 & - & - & - \\
\hline
\end{tabular}

${ }^{*}$ Summed features are groups of two or three fatty acids that cannot be separated by GLC with the MIDI system. Summed feature 1 contained iso- $\mathrm{C}_{15: 1} \mathrm{H}$ and/or iso- $\mathrm{C}_{15: 1} \mathrm{I}$ and/or $\mathrm{C}_{13: 0}$ 3-OH; summed feature 3 contained $\mathrm{C}_{16: 1} \omega 7 c$ and/or iso- $\mathrm{C}_{15: 0} 2-\mathrm{OH}$; summed feature 4 contained iso- $\mathrm{C}_{17: 1} \mathrm{I}$ and/or anteiso- $\mathrm{C}_{17: 1} \mathrm{~B}$.
Mucilaginibacter (Table 1). Therefore, strain WPCB $133^{\mathrm{T}}$ should be classified as a novel species within the genus Mucilaginibacter, for which the name Mucilaginibacter rigui sp. nov. is proposed. On the basis of new data obtained by Urai et al. (2008) and in this study, an emended description of the genus Mucilaginibacter is also proposed.

\section{Emended description of the genus Mucilaginibacter Pankratov et al. 2007 emend. Urai et al. 2008}

The description of the genus Mucilaginibacter is as given by Pankratov et al. (2007) and emended by Urai et al. (2008) with the following modifications. Oxidase activity, hydrolysis of aesculin, pectin, starch and xylan, production of flexirubin-type pigments and cyclic cell shape change are species-dependent. Show strictly aerobic or facultatively anaerobic metabolism. The predominant quinone is MK-7, but some species contain MK-6 as well. The major fatty acids are straight- and branched-saturated fatty acids, but some species contain summed feature $3\left(\mathrm{C}_{16: 1} \omega 7 c\right.$ and/or iso- $\left.\mathrm{C}_{15: 0} 2-\mathrm{OH}\right)$ as well. The DNA $\mathrm{G}+\mathrm{C}$ content varies between 42.4 and $47 \mathrm{~mol} \%$.

\section{Description of Mucilaginibacter rigui sp. nov.}

Mucilaginibacter rigui (ri.gu'i. L. gen. n. rigui of a wellwatered place).

Cells are Gram-reaction-negative, non-endospore-forming, non-motile, aerobic rods, $0.3-0.4 \mu \mathrm{m}$ in diameter and $1.0-$ $1.7 \mu \mathrm{m}$ long, occurring singly or in pairs (Supplementary Fig. S1 available in IJSEM Online). No cyclic cell shape change is noticed during culture. Colonies on R2A agar are circular, convex with entire margins, mucoid, translucent, pale pink and approximately $3.0 \mathrm{~mm}$ in diameter after 3 days at $25{ }^{\circ} \mathrm{C}(\mathrm{pH} 7)$. Good growth occurs on R2A, MM1, PCA and TSA, but only weak growth occurs on NA. Large amounts of extracellular polymeric substances are produced. Growth occurs at $\mathrm{pH}$ 5-10 (optimum, $\mathrm{pH}$ 6-7) and at $4-37^{\circ} \mathrm{C}$ (optimum, $25^{\circ} \mathrm{C}$ ). $\mathrm{NaCl}$ inhibits growth at concentrations above $1 \%(\mathrm{w} / \mathrm{v})$. Flexirubin-type pigments are absent. Oxidase- and catalase-positive. Positive for hydrolysis of Tween 20, but negative for hydrolysis of alginate, casein, cellulose, chitin, CM-cellulose, pectin, starch, Tween 80, L-tyrosine and xylan. Acid is produced from galactose, lactose, maltose, mannose and sucrose, but not from cellobiose, fructose, glucose, rhamnose, xylan and xylose. Positive reactions (API 20E and 20NE systems) for acetoin production, aesculin hydrolysis, $\beta$-galactosidase activity and assimilation of $\mathrm{N}$-acetyglucosamine, glucose, mannose and maltose. Negative reactions for arginine dihydrolase, gelatinase, lysine decarboxylase, ornithine decarboxylase, tryptophan deaminase and urease activities, utilization of citrate, production of indole and $\mathrm{H}_{2} \mathrm{~S}$, nitrate reduction, oxidation of amygdalin, arabinose, inositol, mannitol, melibiose, rhamnose, sorbitol and sucrose, fermentation of glucose, and assimilation of adipate, arabinose, caprate, potassium gluconate, malate, mannitol, 
phenylacetate and trisodium citrate. In the API $50 \mathrm{CH}$ system, acid is produced from $\mathrm{N}$-acetylglucosamine, aesculin, amygdalin, arbutin, cellobiose, D-galactose, Dglucose, lactose, maltose, D-mannose, methyl $\alpha$-D-glucopyranoside, methyl $\alpha$-D-mannopyranoside, melibiose, salicin, sucrose and trehalose; acid is not produced from Dadonitol, D- or L-arabinose, D- or L-arabitol, dulcitol, erythritol, D-fructose, D- or L-fucose, gentiobiose, glycerol, glycogen, inositol, inulin, D-lyxose, D-mannitol, melezitose, methyl $\beta$-D-xylopyranoside, potassium gluconate, potassium 2-ketogluconate, potassium 5-ketogluconate, raffinose, L-rhamnose, D-ribose, D-sorbitol, L-sorbose, starch, D-tagatose, turanose, xylitol or D- or L-xylose. In the API ZYM gallery, $N$-acetyl- $\beta$-glucosaminidase, acid phosphatase, alkaline phosphatase, esterase (C4), esterase lipase (C8), $\alpha$-galactosidase, $\beta$-galactosidase, $\alpha$-glucosidase, $\beta$ glucosidase, leucine arylamidase, $\alpha$-mannosidase, naphthol-AS-BI-phosphohydrolase and valine arylamidase activities are present; but $\alpha$-chymotrypsin, cystine arylamidase, $\alpha$-fucosidase, $\beta$-glucuronidase, lipase (C14) and trypsin activities are absent. Positive for Biolog GN2 MicroPlate substrates $N$-acetyl-D-glucosamine, cellobiose, dextrin, gentiobiose, $\alpha$-D-glucose, lactose, lactulose, maltose, D-mannose, melibiose, methyl $\beta$-D-glucoside, raffinose, sucrose, trehalose and turanose, but negative for acetic acid, $N$-acetyl-D-galactosamine, cis-aconitic acid, adonitol, L-alaninamide, D- and L-alanine, L-alanyl glycine, $\gamma$-aminobutyric acid, 2-aminoethanol, L-arabinose, Darabitol, L-asparagine, L-aspartic acid, bromosuccinic acid, 2,3-butanediol, D- and L-carnitine, citric acid, $\alpha$-cyclodextrin, i-erythritol, formic acid, D-fructose, L-fucose, Dgalactonic acid lactone, D-galactose, D-galacturonic acid, D-gluconic acid, D-glucosaminic acid, glucose 1-phosphate, glucose 6-phosphate, glucuronamide, D-glucuronic acid, Lglutamic acid, glycerol, D- and L- $\alpha$-glycerol phosphate, glycogen, glycyl L-aspartic acid, glycyl L-glutamic acid, Lhistidine, $\alpha-, \beta$ - and $\gamma$-hydroxybutyric acids, $p$-hydroxyphenylacetic acid, L-hydroxyproline, inosine, myo-inositol, itaconic acid, $\alpha$-ketobutyric acid, $\alpha$-ketoglutaric acid, $\alpha$ ketovaleric acid, D- and L-lactic acid, L-leucine, malonic acid, D-mannitol, L-ornithine, L-phenylalanine, phenylethylamine, L-proline, propionic acid, D-psicose, putrescine, L-pyroglutamic acid, pyruvic acid methyl ester, quinic acid, L-rhamnose, D-saccharic acid, sebacic acid, D- and Lserine, D-sorbitol, succinamic acid, succinic acid, succinic acid monomethyl ester, L-threonine, thymidine, Tweens 40 and 80 , uridine, urocanic acid and xylitol. Sensitive to the following antibiotics ( $\mu \mathrm{g}$ per disc, unless otherwise indicated): chloramphenicol (30), ciprofloxacin (5), nalidixic acid (30), rifampicin (5) and tetracycline (30). Resistant to the following antibiotics ( $\mu$ g per disc, unless otherwise indicated): amikacin (30), ampicillin (10), aztreonam (30), cephalothin (30), cefepime (30), cefmetazole (30), cefotaxime (30), ceftazidime (30), ceftriaxone (30), erythromycin (15), gentamicin (10), imipenem (10), isepamicin (30), kanamycin (30), lincomycin (2), moxalactam (30), nitrofurantoin (300), oxacillin (1), penicillin (10 IU), piperacillin (100), streptomycin (100), teicoplanin
(30), ticarcillin/clavulanic acid (75/10), tobramycin (10) and vancomycin (30). The major fatty acids $(>25 \%)$ are iso- $\mathrm{C}_{15: 0}$ and anteiso- $\mathrm{C}_{15: 0}$. The complete fatty acid composition is given in Table 2. The DNA G $+\mathrm{C}$ content of the type strain is $47 \mathrm{~mol} \%$. The only respiratory quinone detected is menaquinone 7 (MK-7).

The type strain is WPCB $133^{\mathrm{T}}\left(=\mathrm{KCTC} 12534^{\mathrm{T}}=\mathrm{NBRC}\right.$ $101115^{\mathrm{T}}$ ), isolated from freshwater of Woopo wetland, Republic of Korea.

\section{Acknowledgements}

This work was supported by the 21C Frontier Microbial Genomics and Applications Center Program, Ministry of Education, Science \& Technology, Republic of Korea.

\section{References}

Bernardet, J.-F., Nakagawa, Y. \& Holmes, B. (2002). Proposed minimal standards for describing new taxa of the family Flavobacteriaceae and emended description of the family. Int J Syst Evol Microbiol 52, 1049-1070.

Chun, J. \& Goodfellow, M. (1995). A phylogenetic analysis of the genus Nocardia with 16S rRNA gene sequences. Int J Syst Bacteriol 45, 240-245.

Chun, J., Bae, K. S., Moon, E. Y., Jung, S. O., Lee, H. K. \& Kim, S. J. (2000). Nocardiopsis kunsanensis sp. nov., a moderately halophilic actinomycete isolated from a saltern. Int J Syst Evol Microbiol 50, 1909-1913.

CLSI (2003). Performance standards for antimicrobial disk susceptibility tests, 8th edn. Approved Standard M2-A8. Wayne, PA: Clinical Laboratory Standards Institute.

Collins, M. D. (1985). Analysis of isoprenoid quinones. Methods Microbiol 18, 329-366.

Felsenstein, J. (1985). Confidence limits on phylogenies: an approach using the bootstrap. Evolution 39, 783-791.

Fitch, W. M. \& Margoliash, E. (1967). Construction of phylogenetic trees. Science 155, 279-284.

Floyd, M. M., Tang, J., Kane, M. \& Emerson, D. (2005). Captured diversity in a culture collection: case study of the geographic and habitat distribution of environmental isolates held at the American Type Culture Collection. Appl Environ Microbiol 71, 2813-2823.

Jukes, T. H. \& Cantor, C. R. (1969). Evolution of protein molecules. In Mammalian Protein Metabolism, pp. 21-132. Edited by H. N. Munro. New York: Academic Press.

Kovacs, N. (1956). Identification of Pseudomonas pyocyanea by the oxidase reaction. Nature 178, 703.

Marmur, J. \& Doty, P. (1962). Determination of the base composition of deoxyribonucleic acid from its thermal denaturation temperature. J Mol Biol 5, 109-118.

MIDI (1999). Sherlock Microbial Identification System Operating Manual, version 3.0. Newark, DE: MIDI, Inc.

Pankratov, T. A., Tindall, B. J., Liesack, W. \& Dedysh, S. N. (2007). Mucilaginibacter paludis gen. nov., sp. nov. and Mucilaginibacter gracilis sp. nov., pectin-, xylan- and laminarin-degrading members of the family Sphingobacteriaceae from acidic Sphagnum peat bog. Int $J$ Syst Evol Microbiol 57, 2349-2354. 
Saitou, N. \& Nei, M. (1987). The neighbor-joining method: a new method for reconstructing phylogenetic trees. Mol Biol Evol 4, 406-425.

Smibert, R. M. \& Krieg, N. R. (1994). Phenotypic characterization. In Methods for General and Molecular Bacteriology, pp. 607-654. Edited by P. Gerhardt, R. G. E. Murray, W. A. Wood \& N. R. Krieg. Washington, DC: American Society for Microbiology.

Stackebrandt, E. \& Goebel, B. M. (1994). Taxonomic note: a place for DNA-DNA reassociation and $16 \mathrm{~S}$ rRNA sequence analysis in the present species definition in bacteriology. Int J Syst Bacteriol 44, 846-849.

Staley, J. T. (1968). Prosthecomicrobium and Ancalomicrobium, new prosthecate freshwater bacteria. J Bacteriol 95, 1921-1944.
Steyn, P. L., Segers, P., Vancanneyt, M., Sandra, P., Kersters, K. \& Joubert, J. J. (1998). Classification of heparinolytic bacteria into a new genus, Pedobacter, comprising four species: Pedobacter heparinus comb. nov., Pedobacter piscium comb. nov., Pedobacter africanus sp. nov. and Pedobacter saltans sp. nov. Proposal of the family Sphingobacteriaceae. Int J Syst Bacteriol 48, 165-177.

Swofford, D. L. (1998). Phylogenetic analysis using parsimony (PAUP). Version 4. Sunderland, MA: Sinauer Associates.

Urai, M., Aizawa, T., Nakagawa, Y., Nakajima, M. \& Sunairi, M. (2008). Mucilaginibacter kameinonensis sp. nov., isolated from garden soil. Int J Syst Evol Microbiol 58, 2046-2050. 